\title{
First Report of Whitefly Transmitted Begomovirus Infecting Chilli in Sub- Himalayan Zone (Cooch Behar) of West Bengal, India
}

\author{
Uday Bikash Oraon ${ }^{1 *}$, Lourembam Sanajaoba Singh ${ }^{1}$ and Jayanta Tarafdar ${ }^{2}$ \\ ${ }^{1}$ Department of Plant Pathology, Bidhan Chandra Krishi Viswavidyalaya, Mohanpur, Nadia- \\ 741252, West Bengal, India \\ ${ }^{2}$ AICRP on Tuber crops, Directorate of Research, Bidhan Chandra Krishi Viswavidyalaya, \\ Kalyani, Nadia-741235, West Bengal, India \\ *Corresponding author
}

\begin{tabular}{|c|c|}
\hline \multicolumn{2}{|r|}{ A B S T R A C T } \\
\hline & \multirow{7}{*}{$\begin{array}{l}\text { Chilli leaf curl disease, caused by the begomovirus (family- Geminiviridae), is an } \\
\text { economically important disease of chilli (Capsicum annum L.) that can be very destructive } \\
\text { in tropical and subtropical regions. In July- august } 2015 \text {, upward leaf-curling, distortion, } \\
\text { vein yellowing or more generalized leaf yellowing and/or stunted growth with bushy } \\
\text { appearance with high abundance of vector whitefly (Bemisia tabaci) observed in chilli } \\
\text { plants in the area of Cooch Behar, a diverse agroclimatic zone of sub Himalayan West } \\
\text { Bengal, India. The incidence begomovirus infection on chilli was observed up to an extent } \\
\text { of } 20-90 \% \text {. Presence of begomovirus infection was confirmed through Polymerase chain } \\
\text { reaction (PCR) using begomovirus specific degenerate primer SPG1/SPG2. PCR product } \\
\text { of } 920 \text { bp was detected, partially sequenced and has been deposited in NCBI (GeneBank } \\
\text { Accession No. LT622252). The BLASTn analysis was performed with other begomovirus } \\
\text { isolates in the GeneBank database of NCBI. The replication associated protein (AC1) gene } \\
\text { of the virus showed highest } 94 \% \text { nucleotide sequence identity (nsi) with both Tomato leaf } \\
\text { curl Joydebpur virus clone Moh9, complete genome [GeneBank Acc. No.- KJ028211] and } \\
\text { Tomato leaf curl Joydebpur virus clone HJP09 segment DNA-A, complete sequence } \\
\text { [GeneBank Acc. No. JQ654463]. This is the first report of a Begomovirus infecting chilli } \\
\text { (Capsicum annum L.) in sub-Himalayan regions of West Bengal. }\end{array}$} \\
\hline Keywords & \\
\hline Chilli, & \\
\hline $\begin{array}{l}\text { Begomovirus, } \\
\text { Whitefly, PCR, } \\
\text { BLASTn. }\end{array}$ & \\
\hline Article Info & \\
\hline $\begin{array}{l}\text { Accepted: } \\
21 \text { October } 2017 \\
\text { Available Online: } \\
\text { 10 December } 2017\end{array}$ & \\
\hline & \\
\hline
\end{tabular}

\section{Introduction}

Generally chilli is susceptible to large number of viruses and few are very common in India (Ramakryshnan, 1961; Bidari and Reddy, 1994). Out of the 22 viruses infecting chilli, Begomoviruses causing leaf curl disease are the most devastating and cause substantial losses and in extreme cases reduce yields to zero leading to catastrophic effects on people. The virus is transmitted by whitefly Bemisia tabaci (Genn.) prevails more in tropical and subtropical part of the world and has a very wide host range. Begomovirus pathogens produce characteristic upward leaf-curling, vein yellowing, stunting of plant growth. The Begomovirus comes under the family Geminiviridae (Padidam et al., 1995) (largest known family of a single-stranded DNA virus), and the circular single stranded DNA genome $(2.5-3.0 \mathrm{~kb})$ encapsidated in quasiisometric virions of about $20-30 \mathrm{~nm}$ in 
diameter (Stanley et. al., 2005) and may be mono or bipartite. The Study was under taken to find out the incidence, detection, characterization and phylogenetic analysis of the begomovirus species complexes predominantly occurring and infecting chilli crops in Cooch Behar, sub-Himalayan zone of West Bengal.

\section{Materials and Methods}

\section{Sample collection and survey of disease incidence}

In July- august 2015, chilli leaf samples showing begomovirus infection symptoms (upward leaf-curling, distortion, vein yellowing, stunted growth \& sometimes with bushy appearance of plants) were collected from different farmers' field of Cooch Behar, a diverse agroclimatic zone of sub Himalayan West Bengal. Infected leaf samples were brought in cool boxes, kept in $-20^{\circ} \mathrm{C}$ for further experiments. Single point method was adopted to know the chilli leaf curl disease incidence at a critical period of crop growth stages. The disease diagnosis in the field was based on typical symptoms. The percent disease incidence was recorded at random in different locations in the field by counting total no of plants and no. of plants showing chilli leaf curl symptoms using the formula given below-

Percent disease incidence $=$

No.of infected plants in the plot

Total no.of plants in the plot $\times 100$

\section{DNA isolation and PCR detection of virus}

Total DNA was extracted from $100 \mathrm{mg}$ of infected and healthy plants using Cetyltrimethyl ammonium bromide (CTAB) method (Dellaporta et al., 1983) and modified by Sharma et al., (2003) was followed for extraction of DNA. Presence of begomovirus was confirmed by PCR amplification with a begomovirus specific degenerate primer pairs SPG1/SPG2 (5' CCCCKGTGCGWRAATCC AT 3' / 5' ATCCVAAYWTYCAGGGAGC TAA 3') (Lotrakul et al., 1998), which amplify replication associated protein (AC1) gene partial segment. The PCR amplification was carried out in a thermal cycler (Mastercycler, Eppendorf, AG 22331, Germany). The PCR reaction mixture contained $2 \mu \mathrm{l}$ DNA sample, $1 \mu$ of each primers (Conc. $10 \mathrm{mM}), 1 \mu \mathrm{l}$ dNTPs (10 $\mathrm{mM}), 1.5 \mu \mathrm{l} \mathrm{MgCl}_{2}$ (25 mM), $2.5 \mu \mathrm{l} 10 \mathrm{x}$ reaction buffer, $0.5 \mu \mathrm{l}$ Taq-polymerase and $15.5 \mu 1$ sterile $\mathrm{HPLC}-\mathrm{H}_{2} \mathrm{O}$, that will give rise to a volume of $25 \mu \mathrm{l}$ PCR reaction. The conditions for $\mathrm{PCR}$ reaction were, an initial denaturation at $94^{\circ} \mathrm{C}$ for 5.00 minute followed by 34 cycles of denaturation at $94^{\circ} \mathrm{C}$ for 30 sec., annealing at $59^{\circ} \mathrm{C}$ for $30 \mathrm{sec}$ and extension for 1 minute at $72^{0} \mathrm{C}$. Then final extension at $72^{\circ} \mathrm{C}$ for 7 minute was included. Amplified PCR product were separated by electrophoresis on 1.5\% agarose gel and DNA fragments were visualized using ethidium bromide strain, here $1 \mathrm{~kb}$ DNA ladder (Fermentas, Life Science) is used and documented by Gel documentation system (Vilber- Lormout, France). The expected amplicon of $920 \mathrm{bp}$ were obtained from the DNA of all diseased leaf samples chosen.

PCR product is further amplified up to 200 $\mu \mathrm{L}$ and run on $1 \%$ agarose gel and finally the desired band (920 bp) was purified using gel extraction kit (Gene JET Gel Extraction kit, Thermo Scientific, Lithuania). After the completion of PCR the amplified products were stored in $-4^{0} \mathrm{C}$.

\section{Sequence and phylogenetic analysis}

The complete nucleotide sequences were subjected for similarity search using BLASTn search program (http://www.ncbi.nlm.nih.gov 
/BLAST/). The sequence was submitted to GenBank with legal annotations. The accessions of GenBank were also received (Accession numbers - LT622252). The sequences were compared with equivalent sequences from a range of other geminiviruses present in GenBank. Multiple sequence alignment was carried out using the software clustalW in MEGA version 6.0 (Tamura et al., 2007).

The pair-wise alignments and Percent Identity Matrix of nucleotide and amino acid sequences were performed using ClustalW2 programme from EMBL Sequence Database online. Phylogenetic trees were constructed on matrices of aligned sequences with 1000 bootstrap replicates by using MEGA version 6.0 at its default settings, on the other hand predicting ORFs, the Expasy proteomic server tool was used to translate the set of protein encoding genes.

\section{Results and Discussion}

Disease symptoms and incidence- All the locations surveyed in Cooch Behar had a varying degree of leaf curl incidence and several mild to severe upward leaf curl symptoms with interveinal and marginal chlorosis (Fig. 1a-d) resemble the begomovirus infection on chilli occurring in India and outside of India.

The severely infected plants produced less or no fruit. The disease incidence ranged from $20-90 \%$. In some places infected chilli plants showing mixed infection of mites along with begomovirus was noticed.

\section{PCR detection of the virus}

One set of universal degenerate primers (SPG1/SPG2) were used for amplification and confirmation of the partial replication associated protein gene (AC1) with expected DNA fragment of $920 \mathrm{bp}$ (Fig. 2a-b) from the virus infected samples of Atiliguri-Cooch Behar-West Bengal.

The samples were considered to contain begomovirus when the molecular weight of the amplified products matched with standard reported molecular weights. The AtiliguriCooch Behar-West Bengal chilli leaf curl samples containing viral DNA were then further purified and subjected for sequencing.

\section{Sequencing and phylogenetic analysis}

The partial nucleotide sequence of begomovirus infecting chilli was deposited in the GenBank and assigned with accession numbers LT622252 (565 bp). The Begomovirus associated with Atiliguri-Cooch Behar-West Bengal isolate (LT622252) DNA-A containing replication associated protein (AC1) gene partial and showed highest nucleotide sequence identity (nsi) with Tomato leaf curl Joydebpur virus clone Moh9, complete genome (94\%) [KJ028211]. The nucleotide sequence of Atiliguri- Cooch Behar- West Bengal begomovirus isolate was compared with 10 previously reported begomovirus isolates infecting solanaceous crop, fabaceae family crop, cucurbitaceae, Malvaceae and amaranthaceae family crop (Table 1) and respective begomovirus accessions available from the GenBank (EMBL).

Multiple sequence alignment was carried out using clustalW in MEGA version 6.0 (Tamura et al., 2007). Atiliguri- Cooch Behar- West Bengal begomovirus isolate gave maximum nucleotide sequence identity with 10 GenBank accession with the range $89 \%$ to 94\%. Among them maximum sequence identity was found with the isolates from mohali, India (KJ028211) 94\%; India (JQ654463) 94\%; Bihar, India (KY010624) 93\%; Bangladesh, Rajshahi (KM383747) 92\% (Table 1). 
Fig.1 a-d

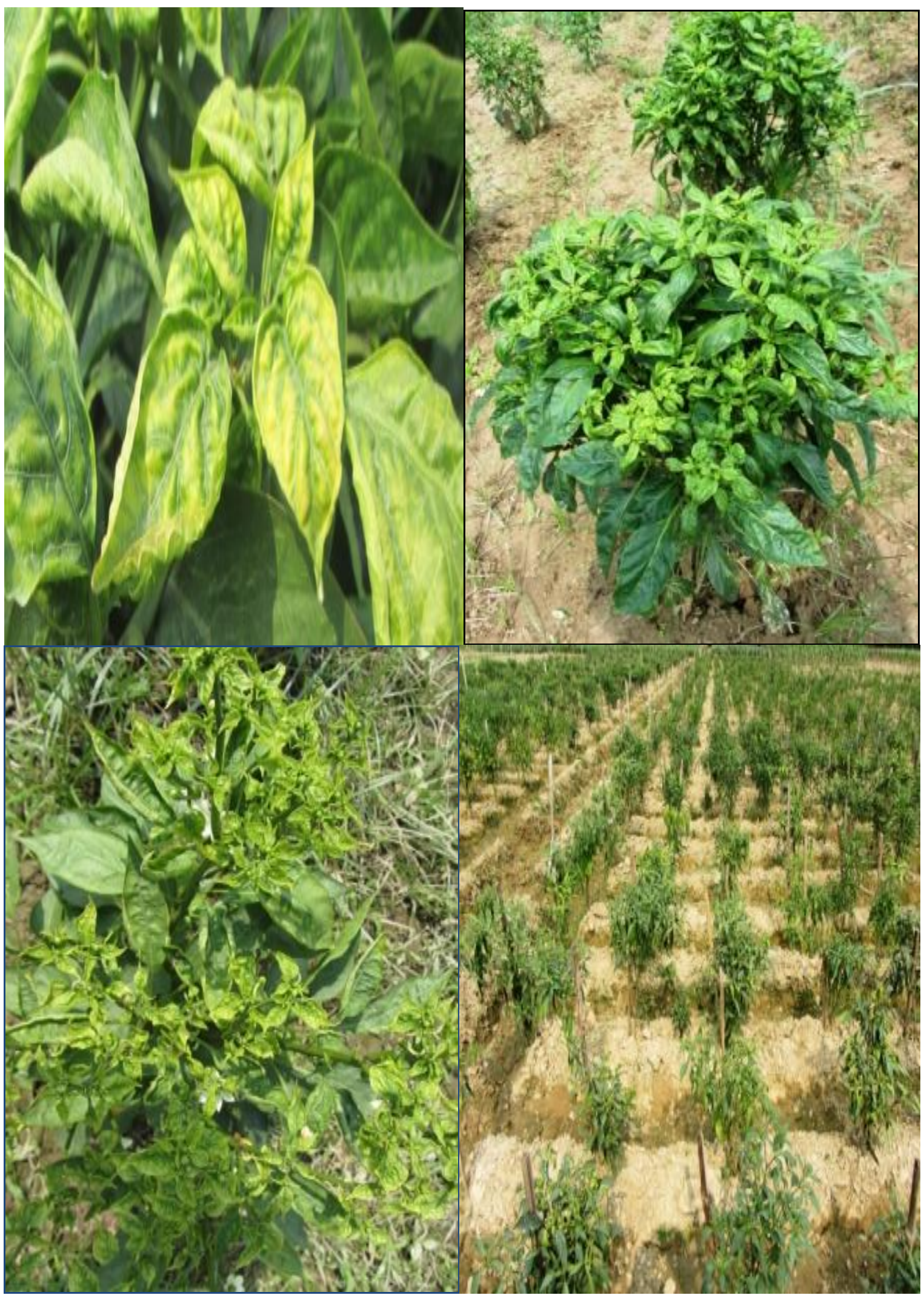


Fig.2a PCR amplification of collected begomovirus samples using degenerate primer pair SPG1/SPG2 sowing the size of amplicon 920 bp; Lane M- 1kb DNA ladder;

1,2- Cooch Behar sample

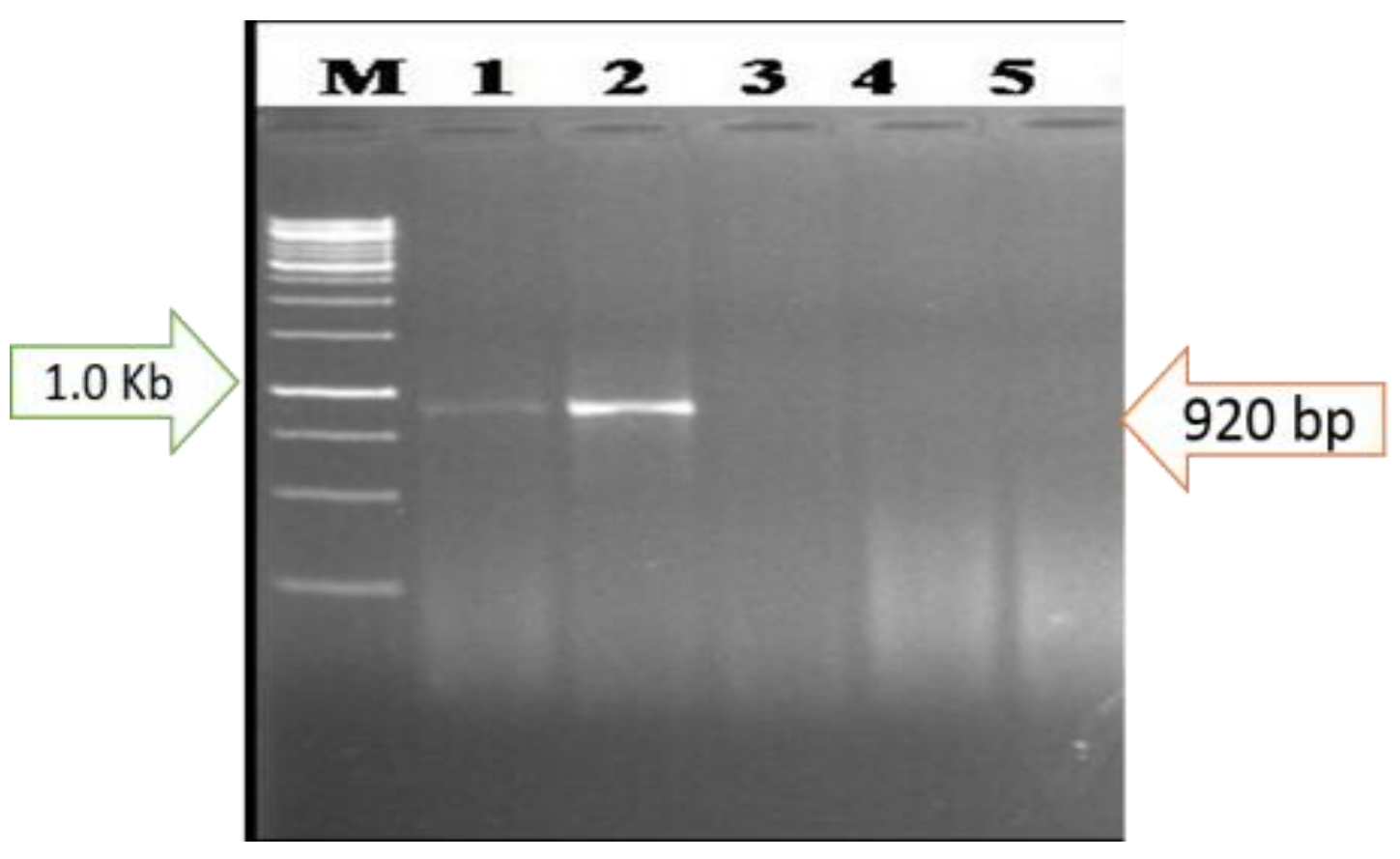

Fig.2b Reconfirmation of the presence of begomovirus infection in chilli sample collected from Cooch Behar; Lane M- 1kb DNA ladder, a- Cooch Behar sample PCR product, b- Healthy sample

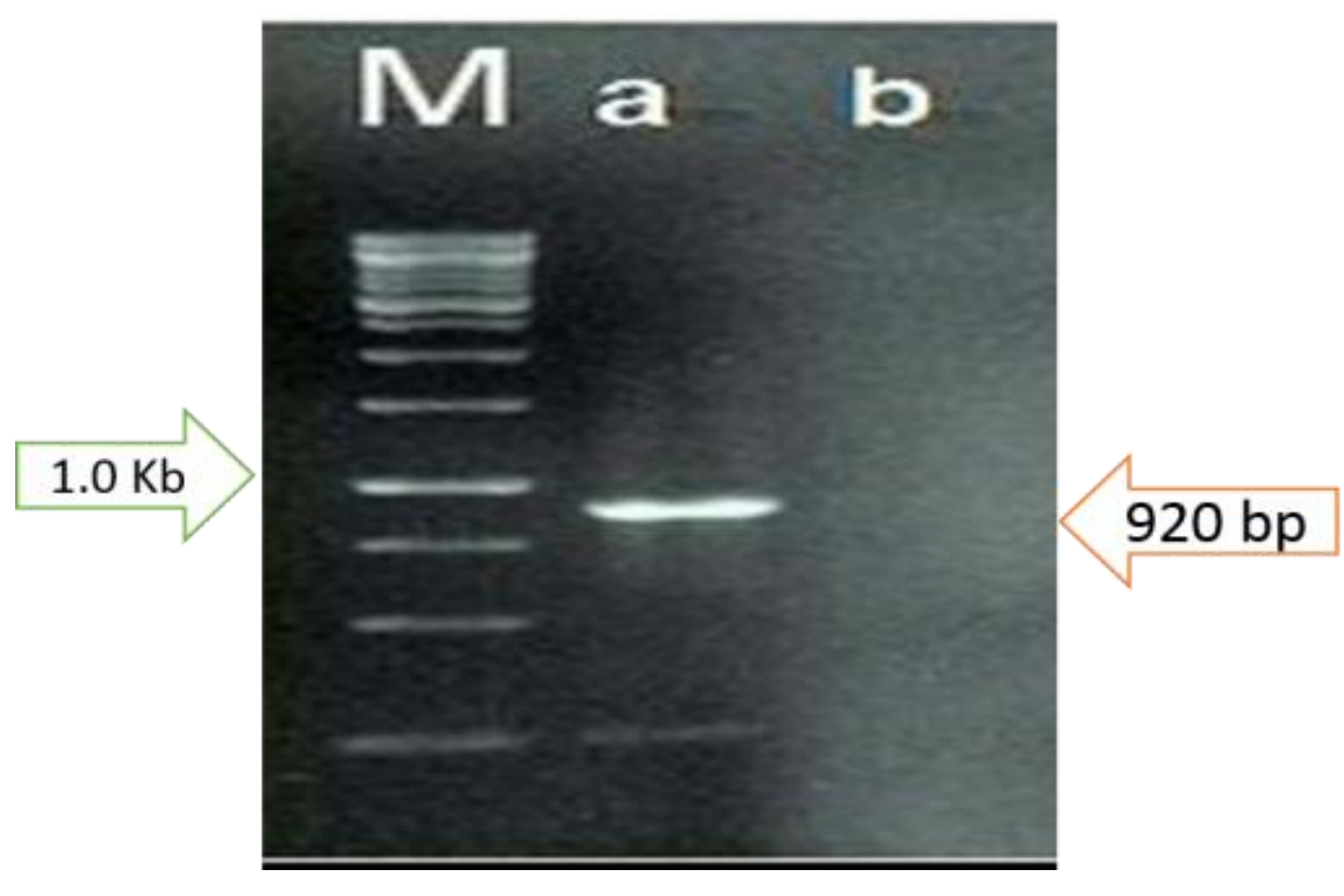


Fig.3 The evolutionary history was inferred using the Neighbor-Joining method [1]. The optimal tree with the sum of branch length $=1.50345365$ is shown. The percentage of replicate trees in which the associated taxa clustered together in the bootstrap test (1000 replicates) are shown next to the branches [2] (next to the branches). The evolutionary distances were computed using the

Maximum Composite Likelihood method [3] and are in the units of the number of base substitutions per site. The analysis involved 11 nucleotide sequences. All positions containing gaps and missing data were eliminated. There were a total of 536 positions in the final dataset.

Evolutionary analyses were conducted in MEGA7 [4].

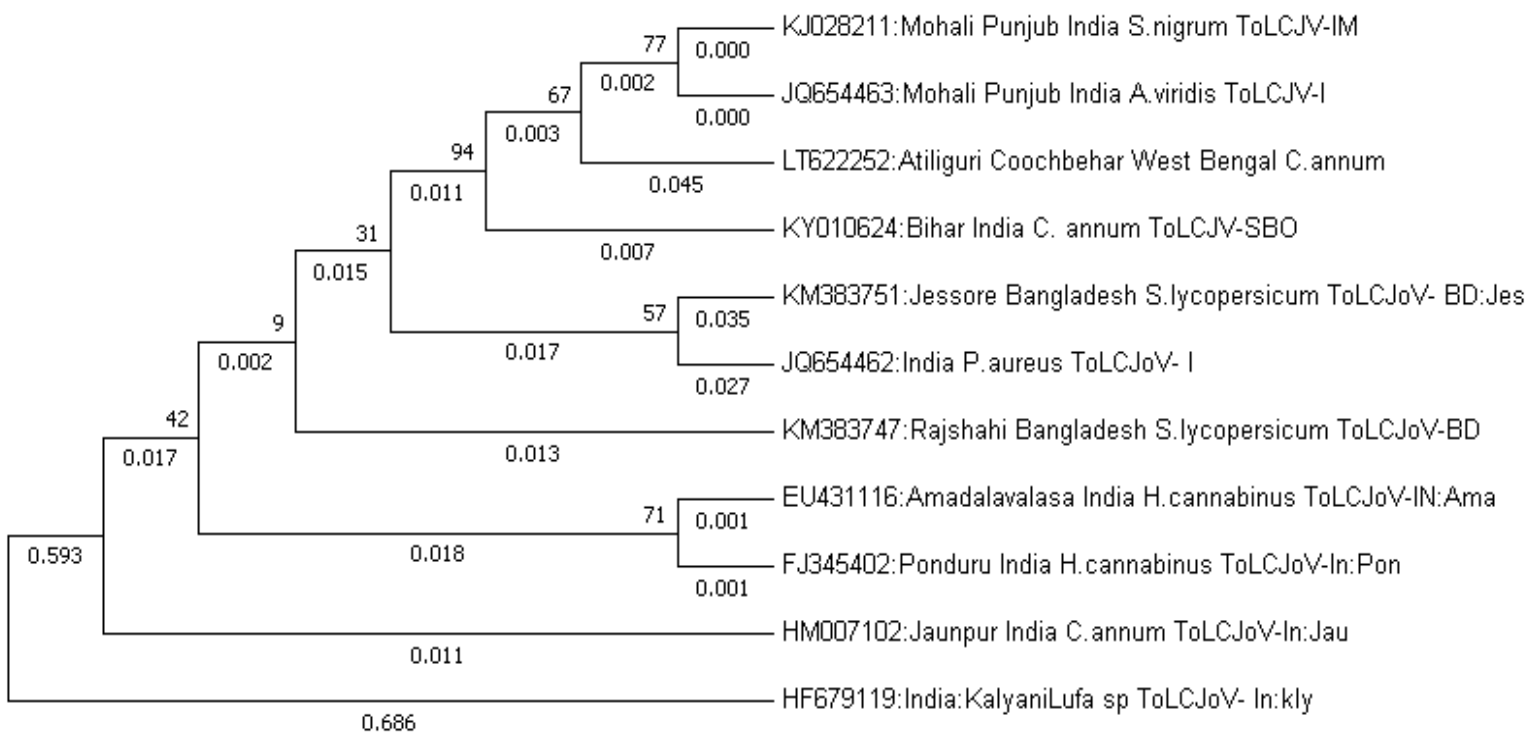

Table.1 List of begomoviruses compared with the atialiguri- Cooch Behar- West Bengal begomovirus isolate in the present study, their origin and NCBI gene accession numbers

\begin{tabular}{|l|l|l|l|}
\hline Virus strains & Acronyms & Origin & Gene Accession No. \\
\hline Tomato leaf curl Joydebpur virus clone Moh9, complete genome & ToLCJV-IM & India & KJ028211 \\
\hline $\begin{array}{l}\text { Tomato leaf curl Joydebpur virus clone HJP09 segment DNA-A, } \\
\text { complete sequence }\end{array}$ & ToLCJV-I & India & JQ654463 \\
\hline $\begin{array}{l}\text { Tomato leaf curl Joydebpur virus isolate ToLCJV-SBO segment } \\
\text { DNA-A, complete sequence }\end{array}$ & ToLCJV-SBO & Bihar, India & KY010624 \\
\hline $\begin{array}{l}\text { Tomato leaf curl Joydebpur virus isolate ToLCJoVBD } \\
\text { [BD:Raj:01:23:Tom:10], complete genome }\end{array}$ & ToLCJoV-BD & Bangladesh & KM383747 \\
\hline $\begin{array}{l}\text { Tomato leaf virus } \\
\text { India:Amadalavalasa1:Kenaf:2007] clone ToLCJVken07 segment } \\
\text { DNA-A, complete sequence }\end{array}$ & ToLCJoV- & India & EU431116 \\
\hline $\begin{array}{l}\text { Tomato leaf curl Joydebpur virus [India:Ponduru:Kenaf:2007] clone } \\
\text { LCPon segment DNA-A, complete sequence }\end{array}$ & $\begin{array}{l}\text { ToLCJoV- } \\
\text { In:Pon }\end{array}$ & India & FJ345402 \\
\hline $\begin{array}{l}\text { Tomato leaf curl Joydebpur virus India [India/Jaunpur/Chilli/2007] } \\
\text { clone pChJauB1 segment DNA-A, complete sequence }\end{array}$ & $\begin{array}{l}\text { ToLCJoV- } \\
\text { In:Jau }\end{array}$ & India & HM007102 \\
\hline $\begin{array}{l}\text { Tomato leaf curl virus [India:KalyaniB.C.K.V.:Ridgegourd:2013] } \\
\text { partial AC1 gene for replication initiation protein, isolate klybckridg9 }\end{array}$ & $\begin{array}{l}\text { ToLCJoV- } \\
\text { In:kly }\end{array}$ & India & HF679119 \\
\hline $\begin{array}{l}\text { Tomato leaf curl Joydebpur virus isolate ToLCJoVBD } \\
\text { [BD:Jes:01:28:Tom:07], complete genome }\end{array}$ & $\begin{array}{l}\text { ToLCJoV- } \\
\text { BD:Jes }\end{array}$ & Bangladesh & KM383751 \\
\hline Tomato leaf curl Joydebpur virus clone HJP07 segment DNA-A & ToLCJoV- I & India & JQ654462 \\
\hline
\end{tabular}


Table. 2 The pairwise sequence comparison with the help of PASC programme (BLAST based Alignment) for Atiliguri-Cooch Behar-West Bengal begomovirus isolate

\begin{tabular}{|c|c|c|c|c|c|c|c|c|c|c|c|}
\hline & $\begin{array}{l}2 \\
\overline{2} \\
\hat{\sigma} \\
6 \\
0\end{array}$ & $\begin{array}{l}\text { ปี } \\
\text { ลู } \\
\text { 与ै }\end{array}$ & 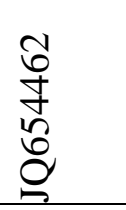 & 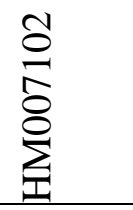 & 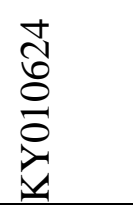 & $\begin{array}{l}n \\
n \\
\infty \\
\infty \\
\sum_{1}^{\infty}\end{array}$ & 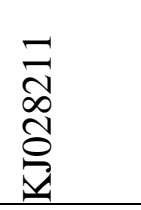 & 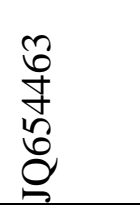 & 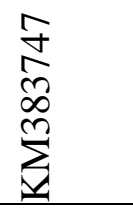 & 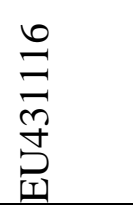 & 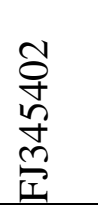 \\
\hline HF679119 & 100.00 & & & & & & & & & & \\
\hline LT622252 & 43.42 & 100.00 & & & & & & & & & \\
\hline JQ654462 & 45.19 & 85.81 & 100.00 & & & & & & & & \\
\hline HM007102 & 46.36 & 85.69 & 92.50 & 100.00 & & & & & & & \\
\hline KY010624 & 45.06 & 89.86 & 90.38 & 92.65 & 100.00 & & & & & & \\
\hline KM383751 & 44.81 & 85.69 & 91.80 & 93.23 & 96.41 & 100.00 & & & & & \\
\hline KJ028211 & 45.45 & 90.58 & 91.67 & 93.23 & 97.10 & 97.61 & 100.00 & & & & \\
\hline JQ654463 & 45.45 & 90.58 & 92.03 & 93.84 & 97.72 & 98.19 & 99.31 & 100.00 & & & \\
\hline KM383747 & 45.32 & 87.86 & 92.48 & 93.91 & 94.31 & 95.36 & 95.61 & 96.23 & 100.00 & & \\
\hline EU431116 & 45.06 & 86.78 & 92.60 & 93.88 & 94.17 & 95.07 & 95.36 & 95.94 & 97.07 & 100.00 & \\
\hline FJ345402 & 45.19 & 86.59 & 92.34 & 93.70 & 93.95 & 94.78 & 95.07 & 95.65 & 96.74 & 99.67 & 100.0 \\
\hline
\end{tabular}

Pair wise matrix based on percent nucleotide sequence identity of Atialiguri Cooch Behar-West Bengal begomovirus isolate infecting chilli and other begomovirus infecting crops of solanaceous, fabaceae, cucurbitaceae, Malvaceae and amaranthaceae family were created by ClustalW2 programme from EMBL Database.

The pairwise sequence comparison with the help of PASC programme (BLAST based Alignment) for Atiliguri-Cooch Behar-West Bengal begomovirus isolate registered a maximum of $92.03 \%$ pairwise alignment with KJ028211 and JQ654463 begomovirus isolates respectively (Table 2).

A phylogenetic tree (Fig. 3) was drawn using the MEGA version 6.0 to analyze the phylogenetic relationship of the sequenced genome of begomoviruses under study with a number of selected begomovirus DNA sequence retrieved from GenBank. The phylogenetic tree was constracted using 10 accessions showing maximum nucleotide identity with isolated Atiliguri-Cooch BeharWest Bengal begomovirus isolate and gave many clusters and sub clusters. Out of 10 accessions, 9 begomovirus belongs to ToLCJV, 1 number of ToLCV. Among these 10 aligned accissions 5 infect solanaceous crop, 1 cucurbitaceae, 2 mallows family crop and 2 infect crops belongs to amaranthaceae family. Phylogenetic tree clearly indicates that Atiliguri- Cooch Behar-West Bengal begomovirus isolate (LT622252) is most closely related to Tomato leaf curl Joydebpur virus clone Moh9, complete genome (94\%) [KJ028211] and the begomovirus isolate were segregated from other chilli infecting begomoviruses in the clusters generated in the phylogenetic tree.

The PCR detection of begomovirus using degenerate primers confirmed the association of begomoviruses with chilli growing in West Bengal, which showed symptoms of mild to severe upward leaf curl symptoms with interveinal and marginal chlorosis, stunting and less or no fruit on infected plant. The variation of symptoms between different chilli growing areas indicated mixed infections with different begomoviruses and mites. According to the results of BLAST analysis, Atiliguri Cooch Behar- West Bengal begomovirus isolate (LT62252) DNA-A containing replication associated protein (AC1) gene 
partial and showed highest nucleotide sequence identity (nsi) with Tomato leaf curl Joydebpur virus clone Moh9, complete genome (94\%) [KJ028211].

If the identities of two different sequences are more than $89 \%$, they are considered to be the variant of same virus (Frauquet and Stanley, 2003). Thus Atiliguri -Cooch Behar- West Bengal begomovirus isolate (LT62252) can be the variant of Tomato leaf curl Joydebpur virus clone Moh9, complete genome (94\%) [KJ028211].

\section{Acknowledgement}

First author is very thankful to Dr. Jayanta Tarafdar and Sanajaoba L. for their support in conducting this study.

\section{References}

Bidari, B.D. and Reddy, H.R. (1994). A survey on mosaic viruses and their distribution in different chilli cultivars in Karnataka. Mysore J. Agric Sci. 28: 52-59.

Dellaporta, S.L., Wood, J. and Hicks, J.B. (1983). A plant DNA minipreparation:
Version III. Plant Molecular Biology

Reporter, 1: 19-21.

http://www.ncbi.nlm.nih.gov/BLAST/

Jeyerajan, R. and Ramakrishnan, K. (1961).

Studies on virus diseases of chilli

(Capsicum sp.). South Indian Hortic., 9 : 1-2.

Lotrakul P., Valverde R.A., Clark C.A., Sim J. and De La Torre R. (1998). Detection of a geminivirus infecting sweet potato in the United States. Plant Disease 82, 1253-7.

Padidam, M., Beachy, R.N. and Fauquet, C.M. (1995). "Tomato leaf curl geminivirus from India has a bipartite genome and coat protein is not essential for infectivity," J. Gen. Virol., 76 (1), 25-35.

Stanley, J., Bisaro, D.M., Briddon, R.W., Brown, J.K., Fauquet, C.M., Harrison, B.D., Rybicki, E.P., and Stenger, D.C. 2005. Family Geminiviridae. Pp. 301326. In: Virus Taxonomy. Eighth Report of the International Committee on the Taxonomy of viruses. Eds: Fauquet, C.M., Mayo, M.A., Maniloff, J., Desselberger, U., and Ball, L.A. Elsevier Academic Press. San Diego, California, USA.

\section{How to cite this article:}

Uday Bikash Oraon, Lourembam Sanajaoba Singh and Jayanta Tarafdar. 2017. First Report of Whitefly Transmitted Begomovirus Infecting Chilli in Sub-Himalayan Zone (Cooch Behar) of West Bengal, India. Int.J.Curr.Microbiol.App.Sci. 6(12): 2960-2967. doi: https://doi.org/10.20546/ijcmas.2017.612.345 